\title{
RUOKOHELVEN VILJELYN KUSTANNUSSÄÄSTÖT JA KILPAILUKYKY
}

\author{
Tapani Tyynelä \\ MTT Etelä-Pohjanmaan tutkimusasema, Alapääntie 104,61400 Ylistaro, Tapani.Tyynela@mtt.fi
}

\section{Johdanto}

Euroopan Unionissa on otettu tavoitteeksi uusiutuvien energialähteiden käytön kaksinkertaistaminen, josta peltoenergian (mm. olki ja ruokohelpi) osuudeksi on arvioitu puolet biomassasta saatavan energian lisäystavoitteesta. Suomessa Kauppa- ja teollisuusministeriön (KTM) johdolla valmistuneessa mietinnössä "Uusiutuvan energian edistämisohjelma 2003-2006" on peltoenergian tavoitteita lisätty (KTM 2002). Ruokohelpi (Phalaris arundinacea) on maassamme luonnonvaraisena kasvava voimakaskasvuinen ja kestävä heinäkasvi. Se on uusiutuvuutensa, suuren hehtaarisatonsa ja kelvollisten poltto-ominaisuuksiensa ansiosta erinomaisesti energian tuotantoon soveltuva viljelykasvi. Ruokohelven viljelyä on tutkittu sekä meillä että Ruotsissa runsaasti 1990-luvulla (esim. Landström ja Wik 1997, Pahkala et al. 2002).

Tuore "Esitys kansalliseksi peltoenergia-ohjelmaksi 2003-2010" arvioi ruokohelven viljelyn olevan käytännössä mahdollista Suomessa 170000 hehtaarin alalla, jolloin sen arvo energiantuotannossa olisi 4.6 TWh (Finbio 2003). Ruokohelven poltto-ominaisuudet ovat paremmat kuin oljen, jonka käyttäminen on riskialtista mm. voimalaitoksen kattilan likaantumisen osalta (Poikola 2001). Vuonna 2003 Suomessa oli viljelyssä 2700 ha ruokohelpeä, josta valtaosa uusiokäytössä olevilla turvesoilla. Kyselytutkimuksessa jopa $70 \%$ vastanneista viljelijöistä on ollut halukkaita tuottamaan ruokohelpeä, mikäli siitä maksettaisiin tyydyttävä eli turvetta vastaava hinta (Klemola et al. 2000).

Maatalouspoliittiset toimenpiteet (tuet, verot ja tuotantokiintiöt jne.) vaikuttavat maatalouden tuotantosuuntien absoluuttiseen ja suhteelliseen kannattavuuteen ja sitä kautta viljelijöiden tuotantopanosten (maatalousmaa, lannoitteet ja torjunta-aineet) käyttöön (Laurila et al. 2003). Nykyisin ruokohelven viljelystä maksetaan non food-kesannon tukea, joka on huomattavasti viljan tukea pienempi. Marraskuussa 2003 tehtiin eduskunnassa toimenpidealoite ympäristötuen saamiseksi non food-kesantona viljeltävälle ruokohelvelle.

Ruokohelven viljelyn ja energiantuotannon kilpailukykyyn vaikuttavat monentyyppiset maatalouspolitiikan toimenpiteet ja muut yhteiskunnalliset ohjauskeinot. Tässä tutkimuksessa tarkastellaan maanviljelijän näkökulmasta viljelyn liiketaloudelliseen kannattavuuteen vaikuttavia tekijöitä. Kustannussäästöjä, tehokasta logistiikkaa sekä markkinoiden toimivuutta arvioidaan pyrittäessä optimaaliseen viljelytulokseen. Ohjauskeinoista huomioidaan maataloustuki ja energiaverotus. Myös vuonna 2005 alkavan päästökaupan vaikutuksista ruokohelvestä maksettavaan hintaan tehdään suuntaa-antavia arvioita. Tulosten perusteella pyritään luomaan kokonaiskuva viljelyn kannattavuudesta nykyisessä tilanteessa. Sitä verrataan viljelijöiltä ja muilta alan ammattilaisilta saatuun palautteeseen.

\section{Aineisto ja menetelmät}

MTT Etelä-Pohjanmaan tutkimusasemalla vuoden 2003 alussa käynnistyneessä Ruokohelvestä energiaakehitysprojektissa on käytännön tarpeista nousevia kysymyksiä tarkasteltu laajemmista näkökulmista. Tämän tutkimuksen tulokset perustuvat projektin henkilökohtaisissa tapaamisissa ja puhelinkeskusteluissa kerättyyn aineistoon. Runsaiden kontaktien ansiosta on voitu tarkastaa esille nousseiden asioiden merkitys ja todenperäisyys monista eri lähteistä. Keskeisiä tiedonlähteitä ovat olleet keskustelut seuraavia ryhmiä edustavien henkilöiden kanssa:

-maanviljelijät ja urakoitsijat (yli 400 viljelijää infotilaisuuksissa ja lisäksi yli 200 puhelua)

-kuntien maaseutuasiamiehet tai maataloussihteerit (12 henkilöä) 
-maaseutukeskuksen neuvojat ja virkamiehet (10 henkilöä)

-voimalaitosten johtajat ja henkilökunta (10 henkilöä)

-suomalaiset ja ruotsalaiset tutkijat (10 henkilöä)

-tullihallituksen ja tullikamarin energiaveroasiantuntijat ( 2 henkilöä)

-maa- ja metsätalousministeriön maatalouspolitiikan ja tukiasioiden virkamiehet (2 henkilöä)

\section{Tulokset ja tulosten tarkastelu}

\section{Optimaalinen viljely, tehokas logistiikka ja toimivat markkinat}

Ruokohelpi tuottaa 6-8 ton/ha polttoaineena hyödynnettävissä olevaa biomassaa. Sen lämpöarvo on kuivana 4.5 MWh/tn (ka) ja keväällä korjattuna $4 \mathrm{MWh} / \mathrm{tn}$ (kosteus $12 \%$ ) (Pahkala et al. 2002). Viljelyn kannattavuutta parantavat erityisesti kustannussäästöt lannoituksessa, korjuussa ja kuljetuksessa. Koska viljelyssä lannoitus nielee kolmanneksen kustannuksista on Pohjanmaalla kokeiltu käytännössä erilaisia lannoitusvaihtoehtoja. Naudan lietelanta, ketunlantakomposti, turvetuhka ja tärkkelysperunan soluneste ovat kaikki osoittautumassa halvoiksi ja tehokkaiksi lannoitteiksi ruokohelvelle. Sen sijaan säästäminen kasvinsuojelussa on kostautunut useille tiloille, joiden pelloilla juolavehnä ja muut rikkakasvit ovat tukahduttaneet ruokohelven kasvun perustamisvuonna. Myös korjuu- ja kuljetuskustannuksia on onnistuttu alentamaan kuljettamalla ruokohelpi voimalaitokselle turpeen kanssa seoskuljetuksena paalikuljetuksen sijaan. Jatkossa luodaan optimaalinen logistiikkaketju myös metsähake-ruokohelpi-seoskuormille.

Keväällä 2003 Pohjolan Voima on laatinut 12-kohtaisen alustavan luonnoksen viljelysopimukseksi. Luonnoksen pohjana on käytetty Ruokohelvestä energiaa-projektille Peltosellun laatimaa raporttia (Myllylä ja Myllylä 2003). Kussakin voimalassa (Seinäjoki, Pietarsaari, Kokkola ja Ylivieska) viimeistellään omat viljelysopimuksensa, koska voimaloiden välillä on eroja hintaan vaikuttavissa tekijöissä (murskaus, varastointi, sähkövero jne.). Sopimusluonnoksen mukaan viljelijälle maksetaan ruokohelpipaaleista pellonreunahinta laatuluokituksen mukaisesti ( $€ /$ tn). Laatuluokkaan vaikuttavat materiaalin kosteus sekä paalien keskipaino.

Tuloksena toimivista markkinoista viljelijöiden kiinnostus ruokohelpeä kohtaan on jatkuvasti noussut. Esimerkiksi keväällä 2003 Pohjanmaalla järjestetyissä seitsemässä viljelyinfossa oli kaikkiaan 400 osallistujaa. Vaikka vain muutama prosentti osallistujista aloitti ruokohelven viljelyn vuonna 2003, niin pinta-alat ovat moninkertaistuneet Pohjanmaalla kahdessa vuodessa. Myönteisen kehityksen jatkuessa tuhannen hehtaarin ala saavutettaneen Pohjanmaalla ehkä jo vuonna 2004. Menekkiä olisi paljon enempäänkin, sillä esimerkiksi 4000 hehtaarin viljelyala kattaisi vasta alle $2 \%$ alueen neljän voimalaitosten vuotuisesta polttoaineen tarpeesta. Tämän suuruinen viljely kivihiilen tai turpeen korvaavaksi polttoaineeksi vähentäisi voimalaitosten hiilidioksidipäästöjä 40000 tonnia.

\section{Päästökaupan vaikutukset, energiaverotus ja maataloustuki}

Euroopan Unionissa aletaan käydä kauppaa teollisuuden kasvihuonepäästöistä vuonna 2005. Järjestelmä koskee usean teollisuusalan ohella yli 20 megawatin energialaitoksia, minkä johdosta fossiilisia polttoaineita käyttävät voimayhtiöt ovat huolissaan sähkön hinnan noususta. Energiayhtiöt ovat tehneet selvityksiä vertailemalla päästökauppa- ja veromuutosten vaikutuksia eri polttoaineiden kilpailukykyyn, käyttömääriin ja hiilidioksidipäästöihin. Selvitysten mukaan hintakilpailukyvyn säilyttämiseksi sähköverot on poistettava, koska verotuksen vaikutus nostaa hintaa heti, kun päästökaupasta tulee huutokauppaperusteinen (Juntunen 2003). Päästökauppa nostaisi todennäköisesti myös ruokohelvestä maksettavaa hintaa. Esimerkiksi Ylivieskan voimalassa hiilidioksiditonnin arvoilla $5 €$ ja $10 €$ ruokohelvestä maksettava hinta nousisi vastaavasti $8 € /$ tn ja $15 € /$ tn.

Ruokohelpi on uusiutuva energianlähde, joten sen kuuluisi saada samanlaisen verokohtelun kuin esimerkiksi metsähake. Sähköveron palautus on nykyisin voimassa puulla, biokaasulla ja kierrätyspolttoaineilla. Metsähakkeelle sähköveron palautus on $6.9 €$ per tuotettu sähkö-MWh. Kun ruokohelpi tuottaa esimerkiksi viiden tonnin (ka) satotasolla $22.5 \mathrm{MWh}$, niin veronpalautus parantaisi huomattavasti ruokohelven tuottajahintaa. Kesällä 2003 Jalasjärven Vasikkanevalla ja Seinäjoen voimalassa käytetty sekakuormien mittaussysteemi osoittautui hyvin käyttökelpoiseksi tarkkuutensa ja 
kustannustehokkuutensa puolesta, joten se tulisi hyväksyä käytännöksi turve-ruokohelpi-seoskuormien energiasisältöjen määrityksessä.

Ruokohelvestä maksetaan maataloustukea joko non-food-kesantona tai sitä alhaisempaa muun nurmen tukea kesannon ulkopuolella. Non food-kesanto sisältää CAP-tuen ja LFA-tuen, mutta ei ympäristötukea. Ympäristötuen saamiseksi nivalalainen kansanedustaja Pekka Vilkuna on marraskuussa 2003 tehnyt eduskunnassa toimenpidealoitteen ympäristötuen maksamisesta. Viljelyn laajentuminen ympäristötuen avulla tukisi hallituksen tavoitteena olevaa kotimaisen energian lisäämistä ja kasvihuonepäästöjen vähentämistä.

\section{Johtopäätökset}

Pohjanmaan voimalaitokset maksavat nyt polttoaineena käyttämästään ruokohelpitonnista turpeen ja metsähakkeen välimaastossa olevaa hintaa, joka nousee välittömästi, mikäli ruokohelpi uusiutuvana energialähteenä saa samanlaisen verokohtelun kuin metsähake. Tulevaisuudessa päästökauppa nostaa edelleen ruokohelvestä maksettavaa hintaa. Ruokohelven viljelyn lisäämiseen tai vähentymiseen ei vaikuta kuitenkaan yksin voimalaitoksen polttoaineesta maksama hinta (Kuvio 1). Maan käytössä tapahtuvat muutokset ovat seurausta laajemmista yhteiskunnallisista ja teknisistä kehityskuluista. Suomessa maatilojen rakennekehitykseen vaikutetaan aktiivisin maatalouspoliittisin toimenpitein. Niemi (2003) muistuttaa, että maatalouden kilpailukyvyn parantaminen ja luonnonvarojen kestävä hyödyntäminen vaativat toteutuakseen sekä kansallisen tuen että muiden kehittämistoimenpiteiden oikeaa kohdentamista.

Nykyinen tukipolitiikka ei suosi ruokohelpeä, sillä non food-kesantona siitä maksetaan viljelijälle tukea vain noin $400 € /$ ha, kun tavallisimmista viljoista maksetaan yli $600 € /$ ha. Juuri tärkein syy siihen ettei ruokohelpi houkuttele viljelijöitä onkin sen heikko asema maataloustuessa. Tilanne muuttuisi, jos non food-kesannolla viljeltävä ruokohelpi saisi ympäristötuen. Pelkästään tukien vuoksi sitä ei kuitenkaan voi viljellä, sillä kunnon satotasoihin pääseminen edellyttää panostuksia varsinkin perustamisvaiheessa.

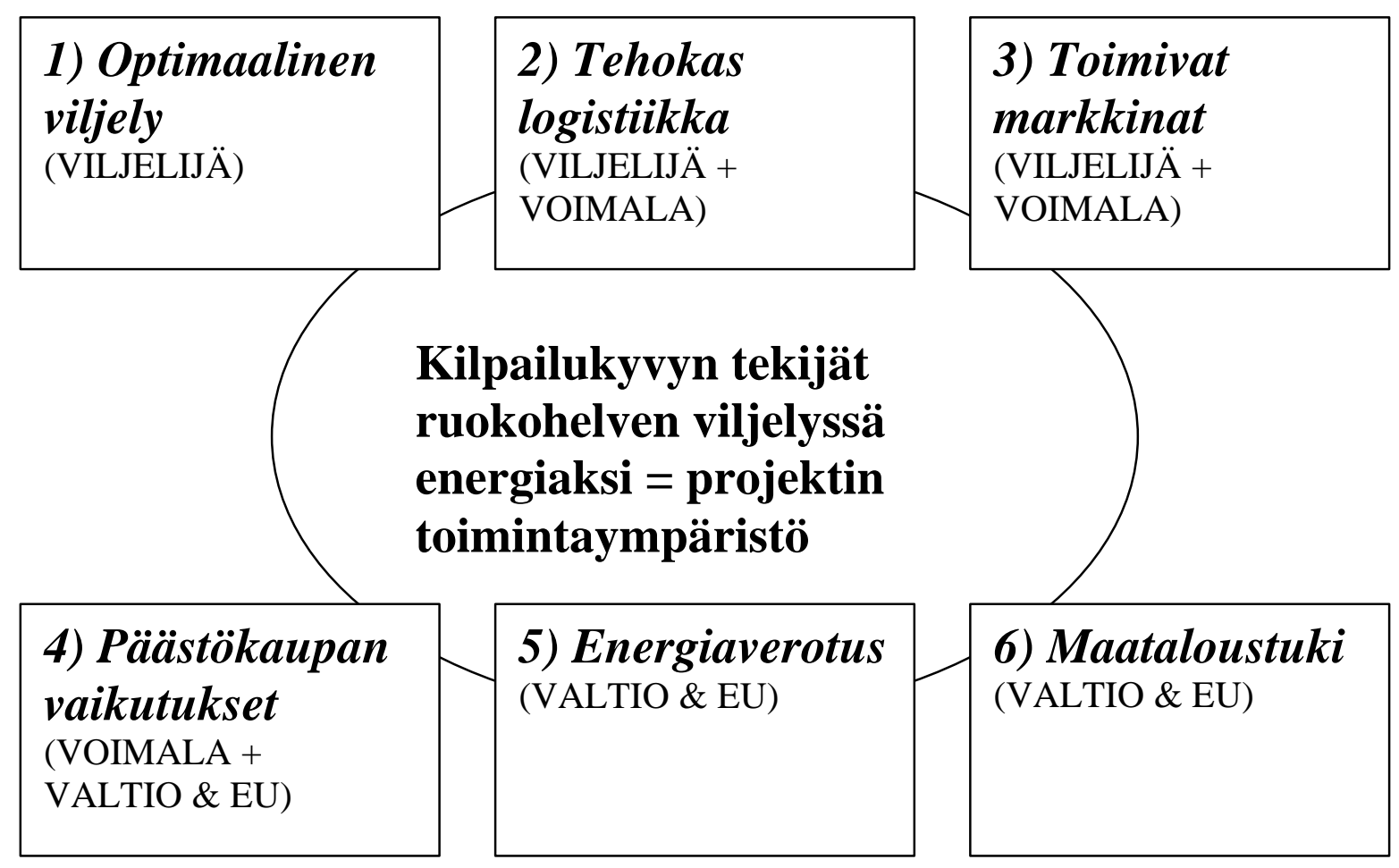

Kuvio 1. Keskeiset kilpailukykyyn vaikuttavat tekijät ruokohelven viljelyssä kuuluvat Ruokohelvestä energiaa-projektin toimintaympäristöön. 


\section{Kirjallisuus}

Finbio. 2003. Esitys kansalliseksi peltoenergia-ohjelmaksi 2003-2010. Suomen Bioenergiayhdistys ry. Julkaisu 25.68 s.

Juntunen. P. 2003. Päästökauppa tulee, olemmeko valmiit? Vierasyliö Maaseudun Tulevaisuudessa 7.5.2003.

Klemola, E., Laine, A. Maunu, T ja Palonen, J. 2000. Ruokohelven ja oljen tuotantokustannus, saatavuus ja korjuuvarmuus. Teoksessa: Salo, R. (toim.) Biomassan tuottaminen kuidun ja energian raaka-aineeksi. Tutkimuksen loppuraportti, osa II. Ruokohelven ja oljen korjuu, tuotantokustannukset ja polttotekniikka. Maatalouden tutkimuskeskuksen julkaisuja. Sarja A 85. Pp. 112-139.

KTM. 2002. Uusiutuvan energian edistämisohjelma. Työryhmän ehdotus. Kauppa- ja teollisuusministeriö. 54 s.

Landström, S. ja Wik, M. 1997. Rörflen. Odling, skörd och hantering. Fakta mark/växter 1.

Laurila, I.P., Huhtala, A., Kantanen, J., Keskitalo, M., Kurppa, A., Kurppa, S., Mäki-Tanila, A., Nissinen, O., Salonen, J., Soini, K., Talkkati, A. ja Sahramaa, M. 2003. MTT:n monimuotoisuustutkimuksen toimenpideohjelma vuosille 2004-2008. 29 s.

Myllylä, M. ja Myllylä, K. 2003. Ruokohelpin kuljetus- ja murskauskustannukset. Selvitykset raportit. Ruokohelvestä energiaa-projekti/Pohjolan Voima Oy.

Niemi, J. 2003. Maataloustuet uusjakoon. Näköalapaikka-kirjoitus, 28.11.2003 Koneviesti.

Pahkala, K., Partala, A., Suokannas, A., Klemola, E., Kalliomäki, T., Kirkkari, A-M., Sahramaa, M., Isolahti, M., Lindh, T. ja Flyktman, M. 2002. Ruokohelven viljely ja korjuu energian tuotantoa varten. Maa- ja elintarviketalous 1: 19 p + 4 liitettä. Saatavissa myös: http://www.mtt.fi/met/met1.pdf>.

Poikola, J. 2001. Ruokohelpi-projektisuunnitelma. Pohjolan Voima oy. 17 s. 